\title{
Wordplay with Phonological Element Contributions in Indonesian Stand-Up Comedy Humor Discourse
}

\author{
Eka Yuli Astuti \\ \{ekajawaunnes@gmail.com\} \\ Universitas Gadjah Mada, Indonesia
}

\begin{abstract}
This study aims to explain the use of phonological aspects in creating word play to arouse humor in Stand-Up Comedy (SUC) in Indonesia. By using sociopragmatic approach, phonological aspects which had potential in producing jokes with the form of word play were analyzed qualitatively. The data in this research were oral data from the SUC which was shown in Kompas TV and Metro TV which were transcribed into written form. Three qualitative data analysis steps were used in this research, such as data reduction, data presentation, and conclusion drawing. The results showed that in the humorous discourse of SUC, the Comics used many phonological aspects such as the use of sound substitution, permutation, insertion, addition of sound, and sound absorption. The phonological aspects were formulated in the form of word plays involving out of language aspects, such as the socio-cultural aspects to create humor in the SUC humorous discourse.
\end{abstract}

Keywords: Humor Discourse, Phonological Aspects, Stand-Up Comedy, Word Play

\section{Introduction}

Stand-Up Comedy is one genre of humorous performances that is still enjoyed by the public in the last ten years. The emergence of Stand-Up Comedy in Indonesia in the early 2000s is a response to the boredom of the public with humorous nuances that already exist. According to its development, SUC in Indonesia was promoted by Ramon Papana. The presence of an open microphone at Ramon Papana's Comedy Cafe, has become a learning medium for delivering SUC material for Stand-Up comedy candidates in Indonesia. Moreover, the presence of the Stand-Up Comedy Indonesia (SUCI) talent program on Kompas TV and several SUC on Metro TV brought SUC to be more recognized by the public.

As one type of humorous performing arts, SUC is a genre that presents a comic as creator of humor and also performer on stage with a microphone. In his/her performance, a comic delivers a series of short humorous stories that originated based on personal unrest in front of the audience on a stage. Comics usually convey material in the form of semi-monologues that allow communication and interactions with the audience. The main purpose of a SUC show is as entertainment that is able to create the jokes to bring laughter to the audience.

To create a joke is required a combination of various aspects. The originality of the story written in the script and using the power of playing language will be the one of an important formula when the script is delivered to the audience on stage. The planning about the use of language when writing a script is a key in SUC show. This is what distinguishes SUC show from other genre humor shows. In humor shows such as Dagelan Mataram, Limbukan in puppet 
shows, Opera Van Java television show, or jokes in some scenes in the Ketoprak show, the actors usually only compile material frameworks, not compile detailed humor scripts.

The writing of humorous script which is then conveyed to the audience generally involves some linguistic aspects, such as phonological aspects, morphological aspects, syntactic aspects, semantic aspects, and also deviations from pragmatic aspects. This article will only discuss the use of phonological aspects to create humor in the humorous discourse of SUC. The use of phonological aspects to create humor is known as a Plesetan or a deviation the original meaning of an utterance. A humorous discourse full of ambiguity can only be created in non-standard forms of language and through violations of pragmatic principles [1].

Each language uses a very limited number of phonemes (so there are so-called phonemes, language sound unit that can produce differences in meaning) and graphemes (letters) which can also occur in certain combinations, so there are many pairs of words that have similar or even identical forms called sound play such as alliteration, assonance and consonance that are formed because of the sound that provides the basis for combining words [2]. This is what led to the variations in sound in phonological studies.

In the discourse of humor, The Comic of SUC utilizes many aspects of phonology in the form of sound games. Some words that have similar sounds but have significant contrasting meanings and have the potential to arouse humor by involving socio-cultural contexts become the means of creating effective humor by comics and easily accepted by the audience. The word plays in the humorous discourse of SUC by involving the sound game is very interesting to be studied because every time, the comics will continue to explore pairs of words that have a similar sound to support the SUC material that will be conveyed (transmitted). This article will discuss the use of phonological aspects in the form of word games involving language sounds in the SUC humorous discourse in Indonesia.

\section{Method}

This research was conducted by using a qualitative-descriptive approach. The data in this research were oral data from the Stand-Up Comedy shown in Kompas TV and Metro TV which was transcribed into written form. Three qualitative data analysis steps were used in this research, such as data reduction, data presentation, and conclusion drawing[3]. Those processes took place continuously during the research, even before the data were actually collected. Data reduction included: (1) summarizing data; (2) coding, (3) tracking theme, and (4) making clusters. Data reduction was done as a part of an analysis to expand, classify, direct, exclude the unnecessary, and organize the data to draw the final conclusion.

\section{Finding and Discussion}

Humor, which utilizes phonological aspects, is formed by using words or phonemes from one's own language to imitate the form of other languages. Utilization of phonological aspects in the form of word games, in a communication process can facilitate the sender of the message to the message recipient to remember or generate information related to current popular culture [4]. Word play is a general term refer to various factual phenomena of language structure features that have a similar form to different meanings which are intentionally used together to cause confusion in communication [2]. In Indonesian, word play to create humor effects can 
utilize phonological aspects such as the use of sound substitution, permutation, insertion, addition of sound, and sound absorption.

\subsection{Sound Substitution}

Sound variations created by replacing one sound with another sound in a word can be used to create humor. The symptom of replacing the sound as mentioned before is called a substitution. One-way comics play with phonemes to create unpredictability is to replace a phoneme in a word with another phoneme so that the audience becomes has misconception.

Utilization of phonological aspects by using sound substitution appears in the following SUC humorous discourse.

Data 1

Gitu loh, cewek itu suka digombalin, makanya gak heran kalau cewek mati itu jenis setan wewe gombal.

'That's it, the girl likes to be flattered, so don't be surprised if she dead, she will become a wewe gombal'

(Stand-Up Comedy Show Metro Tv Episode 1 Januari 2014, Arya Novrianus)

Table 1. Sound Substitution Findings

\begin{tabular}{|l|l|}
\hline \multicolumn{1}{|c|}{ Original message } & \multicolumn{1}{|c|}{ Intended meaning } \\
\hline $\begin{array}{l}\text { Gitu loh, cewek itu suka digombalin, makanya } \\
\text { gak heran kalau cewek mati itu jenis setan } \\
\text { wewe gombal }\end{array}$ & $\begin{array}{l}\text { Gitu loh, cewek itu suka digombalin, } \\
\text { makanya gak heran kalau cewek mati itu } \\
\text { jenis setan wewe gombel }\end{array}$ \\
$\begin{array}{l}\text { 'That's it, the girl likes to be flattered, so don't } \\
\text { be surprised if she dead, she will become a } \\
\text { wewe gombal' }\end{array}$ & $\begin{array}{l}\text { 'That's it, the girl likes to be flattered, so } \\
\text { don't be surprised if she dead, she will } \\
\text { become a wewe gombel' }\end{array}$ \\
\hline \multicolumn{1}{|c|}{ Actual pronunciation } & \multicolumn{1}{|c|}{ Similar pronunciation } \\
$\begin{array}{l}\text { Wewe gombal [wewe gombal] } \\
\text { 'Flattery' } \text { [gombal] }\end{array}$ & $\begin{array}{l}\text { 'Kewe gombel [wewe gombEl] } \\
\text { mythology' woman ghost in Javanese }\end{array}$ \\
\hline
\end{tabular}

In the data (1) the phoneme /a/ in the middle of the word gombal was actually a phoneme /e/ with allophones [E] so it becomes gombel [gombEl]. However, Arya as a comic intentionally replaced the phoneme/e/with/a/to create unpredictability. SUC viewers already knew that the type of ghost that existed in public trust was called wewe gombel. However, Arya intentionally turned them into wewe gombal. This made the audience surprised and had a funny effect.

The emergence of the sound substitution in the word wewe gombel [wewe gombEl] became wewe gombal in socio pragmatic is strongly influenced by the social aspects of language. Arya as a comic who is originally from Bekasi Indonesia, of course, in the social cultural environment has recognized the belief in the kinds of ghost in Indonesia viewed from the mythology the existence of various types of invisible creatures about wewe gombel in almost all around of Indonesia. Indonesian people's beliefs about superstitious things are legitimized in the form of fairy tales, hereditary stories which are then referred to as fictitious myths that 
usually involve figures, supernatural actions and events, and include some general ideas of nature symptoms or historical [5].

The myth of the existence of supernatural beings called wewe gombel, is very closely related to Javanese culture. The myth of Wewe Gombel is believed by the community to frighten children. So that after dusk until evening they do not play outside. By giving the children a warning that if they go out at night, they will be taken by Wewe Gombel, it is hoped that children will be afraid to go out at night. Even if they are forced to go out with their parents, the children are usually put on safety pins or carry small scissors with the belief that they will be heavy if taken by Wewe Gombel [5].

In addition, the myth of wewe gombel also develops in Semarang city. In Semarang city, there is an area called Gombel which is famous for extreme uphill road and quiet. There will still be a lot of people who have crossed the Semarang City Gombel area, which is known as a dangerous and haunted area, and then became a story generation to generation. The story about the existence of wewe gombel becomes the material of horror stories/mystery films/videos. The same knowledge of comic and audiences in cultural about the existence of wewe gombel was used by comic to substitute the sound in the wewe gombel [wewe gombEl] became wewe gombal [wewe gombal] to create humor.

\subsection{Sound Permutation}

Comics have used sound permutations to create humor. Likewise for comics, the use of symptoms of mistakenness is deliberately done to create humor. Below is the use of sound permutation symptoms by comics to create a joke. The following is an example of the use of phonological aspects in the form of sound permutations in SUC humor discourse in Indonesia.

Data 2

.... Santet ini sebenernya sudah ada dan harus di akui sudah ada dilingkungan kita sehari-hari betul. Dan adanya dimalam hari..." santet ayam.... santet kambing" tidak papa kita kan sedang bermain setan bahasa Inggrisnya playsetan.

'.... Santet actually already exists and must be recognized in our daily environment. And at night ... chicken santet ... goat santet". It's okay, we're playing satan, in English is playsetan.'

(Metro TV Stand-Up Comedy Battle of Komika 02 April 2013)

Table 2. Sound Permutation Findings

\begin{tabular}{|l|l|}
\hline \multicolumn{1}{|c|}{ Original message } & \multicolumn{1}{c|}{ Intended meaning } \\
\hline $\begin{array}{l}\text { (2.1) Santet ini sebenernya sudah ada dan } \\
\text { harus di akui sudah ada dilingkungan kita } \\
\text { sehari-hari betul. Dan adanya dimalam } \\
\text { hari...santet ayam.... santet kambing }\end{array}$ & $\begin{array}{l}\text { Sate ini sebenernya sudah ada dan harus di } \\
\text { akui sudah ada dilingkungan kita sehari- } \\
\text { hari betul. Dan adanya dimalam hari...sate } \\
\text { ayam.... sate kambing }\end{array}$ \\
$\begin{array}{l}\text { Santet actually already exists and must be } \\
\text { recognized in our daily environment. And at } \\
\text { night ... chicken santet ... goat santet.' }\end{array}$ & $\begin{array}{l}\text { Satay actually already exists and must be } \\
\text { recognized in our daily environment. And } \\
\text { at night ... chicken satay ... goat satay' }\end{array}$ \\
\hline \multicolumn{1}{|c|}{ Actual pronunciation } & \multicolumn{1}{|c|}{ Similar pronunciation } \\
\hline santet [santEt] & sate [sate] \\
\hline
\end{tabular}




\begin{tabular}{|l|l|}
\hline 'Kind of witchcraft in Indonesian culture' & 'Kind of Indonesian food' \\
\hline \multicolumn{1}{|c|}{ Original message } & \multicolumn{1}{c|}{ Intended meaning } \\
\hline $\begin{array}{l}\text { (2.2) tidak papa kita kan sedang bermain setan, } \\
\text { bahasa Inggrisnya playsetan. }\end{array}$ & $\begin{array}{l}\text { tidak papa kita kan sedang bermain setan } \\
\text { 'It's okay, we're playing satan, in English is } \\
\text { playsetan.' }\end{array}$ \\
\hline Actual pronunciation & $\begin{array}{l}\text { 'It's okay, we're playing satan, in English is } \\
\text { playstation.' }\end{array}$ \\
\hline playsetan [pleisetan] & Similar pronunciation \\
\hline
\end{tabular}

The humorous discourse conveyed by the comics in data (2), there was a pronunciation [santEt] to [satE] in the humor in data (2) deliberately done to confuse the audience's thoughts. Allophones or variations of sounds for phonemes/e/turned out to be a source of ideas for the creation of humor by comics. The phoneme pronunciation/e/in Indonesian has allophones [e] and $[\varepsilon]$.

In data (2) the comic firstly discussed the problem of Santet (kind of witchcraft), but then suddenly the target word in the discourse changes to/sate/'satai' (type of food made from chicken and goat meat which is roasted and pinned in a stick). The audiences' presumption was built more clearly by comic in the discourse when the word santet was attached to the word chicken and goat. So that the audience spontaneously responded to the screaming [satE satE] as if they wanted to justify the pronunciation of comics when they called the terms of chicken santet, goat santet. The symptom of saying [santEt] to [satE] by the comic in discourse (2) was able to cause humor.

Likewise, it was also happened when the comics said the word pleysetan as a form of intentionally wrong utterance with the target word playstation [pleystesien] as a type of game. In creating jokes by utilizing the linguistic aspects of the permutation, it could not be separated from the social elements of language. It was started from choosing a theme about santet (kind of witchcraft). Santet is part of Indonesian people believe in the world of macrocosm and microcosm. The phenomenon of santet is not only developing in Java, in almost all parts of Indonesia is familiar with the term santet. Although living in the era of the industrial revolution 4.0, it seems that terms related to the supernatural world still exist. This is evidenced by the persistence of religious shows in exploring the people who are considered suffering because of being exposed to santet or witchcraft.

Similar with the word sate, the name of a type of food is a typical Indonesian food that is known and easily found in Indonesia. Although sate in Indonesia is identical with Madurese ethnic (sate Madura), in almost all Indonesian people recognize sate as a various type of dishes made from chicken, goat, or beef that is cut into small pieces, stabbed with sticks or bamboo which have been shaved small, given spices, then roasted in charcoal embers. The comic deliberately used the word Sate as a permutation for the word santet because it was considered that both words were sociocultural attached to the mind of the audience.

\subsection{Phoneme Addition}

Phonological variation that potentially creates cuteness is by adding phonemes both in front and behind words. The unexpected addition of a phoneme that can create differences in the meaning of the word is what triggers humor. The addition of consonants at the end of words to produce a humorous effect by comics in the SUC is shown in the following data. 
Data 3

Gitu. Dan menurut gua selain suka digombalin cewek itu adalah makhluk yang manja. Cewek itu manja banget. Beda sama cewek gua. Cewek gua manja tapi manjanya pas 17 an manja pinang.

'So, and in my opinion, besides she likes to be flattered, the girl is a spoiled creature. The girl is really spoiled. It's different with my girl. My girls are spoiled, but only in 17 's event in Independence Day, spoiled areca nut tree'.

(Stand-Up Comedy Show Metro TV,1 Januari 2014, Arya Novrianus)

Data 4

Besi bisa berkarat, karena proses korosi, apa itu korosi? Korosi adalah kerusakan yang disebabkan oleh zat kimia, sedangkan korupsi kerusakan yang disebabkan oleh orang-orang yang nggak bertanggung jawab. Yang seharusnya dimasukkan ke dalam jeruji besi, besi yang berkarat.

'Iron can rust, because of the corrosion process, what is corrosion? Corrosion is damage caused by chemicals, while corruption is damage caused by people who are not responsible. That should be put into prison, in rusted iron".

(Kompas TV, SUCA 2- Big 35 Grup 4, Egi M. Khotib)

Data 5

Di sini depan batangan semua, gak enak banget ya. Gua pengen ngomongin cewek. Menurut gua cewek itu makhluk yang paling suka digombalin. Serius misalkan contohnya mbak itu namanya siapa mbak? (menyapa penonton) mbak..... (sambil menunjuk seorang wanita) Jangan bengong mbak, iya. Tata? Bukti cewek suka digombalin. Tata kamu tahu gak bedanya lukisan sama kamu apa? Lukisan itu makin lama makin antik, kamu makin lama makin cantik.

'Here in front all is only man, it's not very good huh. I want to talk about girls. In my opinion, the girl is a creature who likes to be flattered. Seriously, for example, Hi girls, what's your name? (Ask to an audience) miss ... (pointing at a woman) Don't be dazed miss. Tata? Here is the evidence that girls like to be flattered. Tata, do you know what the difference with your painting is? The painting is getting more and more antique, you are more on more beautiful'.

(Stand-Up Comedy Show MetroTV 1 Januari 2014, Arya Novrianus)

Table 3. Phoneme Addition findings

\begin{tabular}{|l|l|}
\hline \multicolumn{1}{|c|}{ Original message } & \multicolumn{1}{c|}{ Intended meaning } \\
\hline $\begin{array}{l}\text { Cewek gua manja tapi manjanya pas 17an } \\
\text { manja pinang. }\end{array}$ & $\begin{array}{l}\text { Cewek gua manjat tapi manjanya pas 17an } \\
\text { manjat pinang }\end{array}$ \\
$\begin{array}{l}\text { My girl is spoiled but only in the 17's } \\
\text { moment, spoiled an areca nut }\end{array}$ & $\begin{array}{l}\text { My girl is spoiled but only in the 17's } \\
\text { moment, climbing an areca nut }\end{array}$ \\
\hline \multicolumn{1}{|c|}{ Actual pronunciation } & \multicolumn{1}{c|}{ Similar pronunciation } \\
\hline
\end{tabular}




\begin{tabular}{|l|l|}
\hline $\begin{array}{l}\text { manja } \text { [manja] } \\
\text { 'Spoiled, pampered' }\end{array}$ & $\begin{array}{l}\text { manjat [manjat] } \\
\text { 'climb' }\end{array}$ \\
\hline
\end{tabular}

The integration of identical female who had spoiled character and the tradition of Panjat pinang competition which is usually held in every anniversary of the Independence Day of the Republic of Indonesia or known as the 17's event, is connected by comic into a material of humor. Arya's as a comic in data (3) intentionally added the phoneme/t/to the word Manja which was mean ' a bad behavior because always given everything she wants' by adding the consonant phoneme/t/so that it became a word manjat which mean climb. The addition of the consonant phoneme/t/to the word manja created unpredictability in the viewer's mind, because in the set up the discussion was about the behavior of women who have pampered character. However, at the end of the bit, the comic shifted the word Manja to the word manjat following word pinang (areca nut tree) to create humor. The addition of phonemes in the middle of the word appears in the word korosi in data (4). The existence of various corruption cases which had become the headline news in the country, had led to the unrest of comic that was manifested in a material on the humorous discourse of SUC. In data (4) as a set-up, the comic analogous a process of destruction of a material, namely iron with a process of corrosion that causes the decaying of iron. However, in the punch line section, by using language games, phonemes were added so that the word korosi (corrosion) become the word korupsi (corruption). The comic believed that both words almost had same meaning, which is to cause damage.

On the discourse data (4), the comic discussed the premise "iron". The premise "iron" was developed into a rusty iron process called corrosion. In the set-up section, the comic discussed the definitions of corrosion. However, in the punchline section, the comic deliberately made the joke of adding phonemes / $\mathrm{p} /$ in the middle of the word/korosi/ 'corrosion' so that it became a word/korupsi/ 'corruption'

The addition of phonemes at the beginning of words to create joke is utilized by comics appear in data (5). In the discourse humor of SUC data (5), the comic intentionally added the words antik 'antique' with the phoneme/c/so that it became a cantik 'beautiful' to bring up the unexpectedness of the audience. The word antik [antik] 'antique' ---> cantik [cantik] 'beautiful '- addition of phonemes/c/. The word antique according to KBBI (Indonesian Main Dictionary) means 'ancient, but still valuable as a work of art or cultural objects (about goods)'. While the word cantik in KBBI (Indonesian Main Dictionary) means 'molek (the beauty about faces, women's faces) '. The audience's presumption when the comic asked the difference between paintings and women was that paintings were inanimate objects while women were living things. But joke was raised when comics add phonemes / $\mathrm{c} /$ to word antik words to word cantik in the phrase "The painting is getting more and more antik, you are getting more and more cantik".

\subsection{Phoneme Deletion}

Beside the addition of phonemes, removing phonemes in front, in the middle, and behind the words has the potential to create humor. As mentioned by [6] who states that phoneme removal consisted in three types of variation, namely apheresis, syncope and apocope. Following is an example of the use of the linguistic aspects in phoneme removal in the humorous discourse of SUC Indonesia. 
Data 6

Sedih banget gua gak pernah lagi gue nemuin orang kaya dia, gua putus dan gua liat ternyata banyak sekali hal-hal yang dalam pacaran-pacaran gua kangenin, tapi kalau gua liat lagi, ternyata norak. Misalnya gampang gitu kan, paling gampang norak-norakan itu pas lu lagi PDKT-PDKTan. Pas PDKT-PDKTan lo mulai menemukan ada panggilan-panggilan sayang yang menurut gueh itu geli banget yah, kalau misalnya gebetannya gendut dipanggilnya ndut, ndut, bangun dong ndut, gitu kan? kalau misalnya kurus... iyus, iyus gitu kan, kalau misal peyang... eyang, eyang bangun eyang, kalau gueh tet, tet.... Kontet sialan yah!

'I'm so sad I never found someone like her again, I broke up and I saw that there are a lot of things that when I was dating, I miss those things, but if I look again, it become disgusting. For example, that's easy example, the easiest example is when you are dating. When you start to find sweet calls, which is in my opinion is a disgusting thing, yeah, for example, if your man or girl is fat, you called Ndut (fatty), Ndut, wakes up. Right huh? If your girl/man is thin ... iyus, iyus (thin/skinny $\mathrm{man} / \mathrm{girl}$ ) right huh? if she/he is peyang (asymmetric) ... eyang, eyang (grandparents, grandparents) wake up grandparents, if it is me Tet...Tet. ... Damn dwarf, hah!'

(Suci Kompas TV, Season 1 Grand Final, Raditya Dika)

Data 7

Iya lagian kenapa mesti malu jadi tukang cuci piring yang penting kan halal ya kan. Jadi tukang cuci piring juga bisa menghasilkan ini nih.Tangan gatel. Lagian gimana gak gatel coba gue disuruh nyuci piring itu yang bertumpuk-tumpuk ampe segitu tuh.Iya ada piring datang gue cuci, abis gue cuci, gue bilas, abis gue bilas gue elap. Habis elap terbitlah terang cie

'Yeah, anyways why should be ashamed to be a dishwasher. The most important it is halal, right. So, the dishwasher can also produce this. Itchy hands. Anyway, what if it's not itchy, I was told to wash the dishes that were piled up to that extent. Yes, there is a plate coming, I wash it, then, I rinse it, the last I wipe it. After wipe comes lightness.'

Table 4. Phoneme Deletion

\begin{tabular}{|l|l|}
\hline Original message & Intended meaning \\
\hline $\begin{array}{l}\text { Iya ada piring datang gue cuci, abis gue cuci, } \\
\text { gue bilas, abis gue bilas gue elap. Habis elap } \\
\text { terbitlah terang cie }\end{array}$ & $\begin{array}{l}\text { Iya ada piring datang gue cuci, abis gue } \\
\text { cuci, guebilas, abis gue bilas gue elap. Habis } \\
\text { gelap terbitlah terang cie }\end{array}$ \\
$\begin{array}{l}\text { 'Yes, there is a plate coming, I wash it, then, } \\
\text { I rinse it, the last I wipe it. After wipe comes } \\
\text { lightness'. }\end{array}$ & $\begin{array}{l}\text { 'Yes, there is a plate coming, I wash it, then, } \\
\text { comes lightness'. }\end{array}$ \\
\hline Actual pronunciation & Similar pronunciation \\
\hline elap [lap] & gelap [g|lap] \\
\hline
\end{tabular}




\begin{tabular}{|l|l|}
\hline [wipe] & [darkness $]$ \\
\hline
\end{tabular}

According to the data (6), the rise of couple who often gave special calls to their lover caused anxiety in Raditya Dika as a comic which was then compiled into SUC humor material. Raditya Dika in the SUC data (6) deliberately removed phonemes in several words to create humor. In one bit of data (6) there were a lot of phoneme omissions aimed to entertain and make the audience laugh. It is illustrated following data:

$$
\begin{array}{llll}
\text { gendut }[\text { [ondut] } & --->\text { endut } \text { [əndut] } & -- & \text { penghilangan fonem } / \mathrm{g} / \\
\text { kurus } \text { [kurus] } & --->\text { iyus }[\mathrm{iyus}] & -- & \text { penghilangan fonem } / \mathrm{k} / \\
\text { peyang }[\mathrm{peyaG}] & --->\text { eyang }[\mathrm{eyaG}] & -- & \text { penghilangan } \text { fomem } / \mathrm{p} /
\end{array}
$$

Another example of phoneme removal to cause cuteness appears in the following example data (7). Public stigma regarding the existence of prestigious professions such as civil servants, businessmen, members of the Board, doctors, engineers, and so on and professions that were considered not prestigious such as laborers, household administrators, artisans, and other unskilled workers made the source of anxiety of Komika Indra. In the matter of humorous discourse SUC data (7) the comic told his anxiety as a dishwasher. Even though one type of work is halal, it would often be looked contemptible by others.

In the example of utterances in the SUC data humor discourse (7) there was a phonological aspect of removing the phoneme / $\mathrm{g} / \mathrm{in}$ the word Gelap [gəlap] to be elap [əlap]. The word elap has the meaning of wiping or drying with a cloth. The set up built by comic was presenting the audience that he was a dishwashing worker at a restaurant whose job was to wash the plate and then wipe the dishes so the plates dry quickly. But the unexpected was raised when Indra mentioned, Habis elap terbitlah terang. Indra utilized the knowledge of the audience about jargon which was thought to be inherent in the audience knowledge of the female emancipation figure of RA Kartini, that was habis gelap terbitlah terang to turn the word gelap into elap.

\section{Conclusions}

The aspects of language as a form of language creativity are one part that is used in creating humor in the writing of humorous discourse on SUC to convey and deliver the SUC script become a SUC show. A comic is able to use various methods to create word games by utilizing almost all linguistic features, not only lexical means such as idioms and polysemy, but also grammatical and phonetic levels. The use of phonological aspects to create humor in the SUC humorous discourse in Indonesia is done by creating word plays such as the use of sound substitution, sound permutation, insertion, sound addition, and sound deletion. A comic plays with phonemes to create unexpectedness by replacing a phoneme in a word with another phoneme so that the audience will have misconception. The sound game that is often called a plesetan has long been done by comedians to create jokes.

\section{Acknowledgement}

This paper is a small part of the dissertation included in the Doctoral Dissertation Research scheme funded by the Ministry of Research, Technology, and Higher Education in 2019. The 
author also expressed her gratitude to Prof. Dr. I Dewa Putu Wijana, S.U., MA who had guided in writing this article. Special gratitude is also expressed to all the managers of the Doctorate Program of Humanities, Faculty of Cultural Science, Universitas Gadjah Mada, Yogyakarta who have provided the opportunity to gain knowledge.

\section{References}

[1] I. D. P. Wijana, "Stand Up Comedy: Language Play and Its Functions (Systemic Functional Linguistic Approach)," J. Lang. Lit., vol. 16, no. 2, pp. 99-105, 2016.

[2] D. Delabastita, "Introduction," Translator, vol. 2, no. 2, pp. 127-139, 1996.

[3] M. B. Miles and M. A. Huberman, Analisis Data Kualitatif: Buku Sumber Tentang MetodeMetode Baru. 2012.

[4] J. F. M. Basols, "The Sound of Humor: Translation, Culture and Phonological Jokes," Universitat Pompeu Fabra, 2012.

[5] Z. Q. F. Alam, "Hadis Dan Mitos Jawa," Riwayah Juranal Stud. Hadis, vol. 2, pp. 111-122, 2017.

[6] J. S. Badudu, Ilmu Bahasa Lapangan. jakarta: Gramedia, 1985. 